\title{
Hubungan Peranan Posbindu Dengan Peningkatan Kesehatan Lansia Di Desa Sindanghayu Kecamatan Beber Kabupaten Cirebon
}

\author{
${ }^{1}$ Ade Rahayu Prihartini, S.ST., M.Kes \\ ${ }^{1}$ Program Studi Diploma III Kebidanan Poltekes Bhakti Pertiwi Husada \\ Email : nenkdiva@gmail.com
}

\begin{abstract}
Abstrak, Di Indonesia, secara nasional pemanfaatan posbindu masih jauh dari target SPM (Standar Pelayanan Minimal) bidang kesehatan di Kabupaten/Kota untuk pelayanan usila yaitu $70 \%$ dari target $85 \%$. Penelitian ini bertujuan untuk mengetahui hubungan peranan posbindu dengan peningkatan kesehatan lansia di Desa Sindanghayu Kecamatan Beber Kabupaten Cirebon. Jenis penelitian ini merupakan penelitian kuantitatif korelasional dengan pendekatan cross sectional. Populasi penelitian ini adalah seluruh lansia usia 50-70 tahun di Desa Sindanghayu dengan sampel 34 orang dan teknik pengambilan sampelnya accidental sampling. Instrumen penelitian menggunakan kuesioner. Uji hipotesis menggunakan analisis Spearman. Hasil penelitiannya adalahPeranan posbindu di Desa Sindanghayu Kecamatan Beber Kabupaten Cirebon adalah $47,1 \%$ positif dan 52,9\% negatif.Peningkatan kesehatan lansia di Desa Sindanghayu Kecamatan Beber Kabupaten Cirebon adalah 45,1\% tidak ada gangguan dan 55,9\% ada gangguan. Ada hubungan signifikan peranan posbindu dengan peningkatan kesehatan lansia di Desa Sindanghayu Kecamatan Beber Kabupaten Cirebon tahun 2018 dengan p-value 0,001 dan Rho $(\rho) 0,795$.
\end{abstract}

Kata Kunci : Posbindu, Kesehatan Lansia

Abstract In Indonesia, as nationally, the utilization of posbindu is still far from the target of SPM (Minimum Service Standard) of health sector in the regency / city for the service of elderly which is $70 \%$ from $85 \%$ target. This study aims to determine the relationship posbindu role with the improvement of elderly health in the Village Sindanghayu Beber District Cirebon.This type of research is a correlational quantitative research with cross sectional approach. The population of this study is all aged 50-70 years old in Sindanghayu Village with a sample of 34 people and the sampling technique is accidental sampling. The research instrument used questionnaire. Hypothesis test using Spearman analysis. The result of this research is Posbindu role in Sindanghayu Village, Beber District of Cirebon Regency in 2018 is 47,1\% positive and $52,9 \%$ negative. Improvement of elderly health in Sindanghayu Village Beber District of Cirebon Regency is 45,1\% no disturbance and 55,9\% there is interference. There is a significant relationship posbindu role with the improvement of elderly health in Sindanghayu Village Beber District Cirebon District with p-value 0.001 and Rho $(\rho) 0.795$.

Keyword : integrated development post, ederly health 


\section{PENDAHULUAN}

Di Indonesia, secara nasional pemanfaatan posbindu masih jauh dari target SPM (Standar Pelayanan Minimal) bidang kesehatan di Kabupaten/Kota untuk pelayanan usila yaitu 70\% dari target 85\%. (Komnas Lansia, 2013).

Untuk Propinsi Jawa Barat, pemanfaatan posbindu baru mencapai $65 \%$ dari target $85 \%$ dari jumlah lansia sebanyak 4.907.054. Sedangkan untuk Kabupaten Cirebon baru mencapai $62 \%$ dari target $85 \%$ jumlah lansia sebesar 604.899. Sementara untuk Desa Sindanghayu Kecamatan Beber target cakupan pemanfaatan posbindu tahun 2017 hanya mencapai 60,5\% dari target $85 \%$.

Seseorang yang berusia lanjut secara fisiologis dan psikis akan terjadi proses menua (aging process). Proses menua merupakan suatu proses yang alami dan komplek berjalan sepanjang hidup tidak dimulai dari suatu waktu yang pasti.Transisi demografi ke arah menua akan diikuti oleh transisi epidemiologi ke arah penyakit degeneratif seperti rematik, diabetes, hipertensi, jantung koroner, neoplasma.

Angka kesakitan penduduk lanjut usia tahun 2015 sebesar 30,46\% artinya bahwa setiap 100 orang lanjut usia, sekitar 30 orang diantaranya mengalami sakit. Angka kesakitan penduduk lanjut usia perkotaan 27,20\% lebih rendah dibandingkan lanjut usia pedesaan $32,96 \%$. Hal ini menunjukkan bahwa derajat kesehatan penduduk lanjut usia di perkotaan relatif lebih baik dibandingkan lanjut usia di daerah pedesaan. Bila dilihat perkembangannya, derajat kesehatan penduduk lanjut usia relatif tidak berbeda. Angka kesakitan penduduk lanjut usia pada tahun 2014 sebesar 29,98\%, tahun 2015 sebesar 31,11\%, dan tahun 2016 sebesar 30,46 \%. Pola yang serupa terjadi baik di perkotaan maupun di pedesaan (Komnas Lansia,2017).

Data Komnas Lansia menyebutkan bahwa pada tahun 2015 terjadi peningkatan jumlah Angka Kematian Lansia yaitu mencapai 785 / 100.000 lansia dibandingkan tahun 2014 yang berada pada kisaran angka 624 / 100.000 lansia. Penyebab utama kematian lansia adalah penyakit fisik dan psikis. Lima penyakit fisik penyebab utama kematian lansia adalah penyakit degeneratif seperti jantung koroner, stroke, hipertensi dan diabetes. Sedangkan penyebab kematian lansia aspek psikis adalah depresi (Komnas Lansia, 2017).

Masa lansia adalah masa keluhan fisik. Lima penyakit fisik utama yang banyak diderita oleh penduduk usia lanjut di Indonesia adalah anemia dengan persentase sebesar 50\%, penyakit kardiovaskuler seperti hipertensi, stroke dan lain-lain memiliki persentase sebesar $29,5 \%$, infeksi saluran pernafasan sebesar $12,2 \%$, penyakit kanker memiliki persentase sebesar $12,2 \%$ dan TBC memiliki persentase sebesar 11,5\% (Depkes RI 2017).

Menurut Komnas Lansia (2017) secara nasional rata-rata 50,4\% lansia berumur 60 tahun lebih memiliki kesehatan fisik yang tidak baik dalam arti memiliki ketergantungan terhadap orang lain dalam melakukan aktivitas kehidupan sehariharinya. Adapun yang dimaksud dengan aktivitas sehari-hari adalah kegiatan dasar dalam kebidupan, seperti : makan, minum, berjalan, mandi berpakaian, naik turun tempat tidur, buang air besar atau buang air kecil dan sebagainya serta kegiatan pekerjan di luar rumah, seperti berbelanja, mencari nafkah, mengambil pensiun, arisan, pengajian dan lain-lain. Sedangkan data Dinkes Propinsi Jawa 
Barat (2017) menyebutkan bahwa terjadi peningkatan angka ketergantungan lansia dari 46,7\% pada tahun 2015 menjadi 49,2\% pada tahun 2016. Sedangkan data Dinkes Kabupaten Cirebon (2017) menyebutkan lebih dari 39,7\% lansia usia 60-70 tahun tidak mampu mandiri dalam melakukan aktivitas kehidupan sehariharinya.

Salah satu program kesehatan untuk lansia adalah diselenggarakannya Posyandu Lansia atau Posbindu. Salah satu peranan posbindu adalah sebagai penyedia pelayanan kesehatan fisik kepada lansia dan membina lansia agar dapat berperilaku sehat sehingga diharapkan kesehatan fisik lansia mengalami peningkatan.

\section{METODE PENELITIAN}

Penelitian ini merupakan penelitian kuantitatif korelasional dengan pendekatan cross sectional. (Arikunto, 2010)

Populasi dalam penelitian ini adalah seluruh lansia usia 50-70 tahun di Desa Sindanghayu Kecamatan Beber Kabupaten Cirebon yang berjumlah 52 lansia dengan sampel 34 berdasarkan rumus Slovin yang diambil secara accidental sampling yaitu cara pengambilan sampel terhadap populasi yang bertemu saat penelitian dilakukan. (Notoatmodjo, 2012) Instrumen penelitiannya angket. Uji hipotesis menggunakan uji Spearman. (Sugiyono, 2009)

\section{HASIL PENELITIAN \\ Biodata Responden}

Tabel 1

Distribusi Frekuensi Jenis Kelamin Responden

\begin{tabular}{|c|c|c|}
\hline $\begin{array}{c}\text { Jenis Kelamin } \\
\text { Responden }\end{array}$ & F & \% \\
\hline Laki-laki & 8 & 23,5 \\
\hline Perempuan & 26 & 76,5 \\
\hline Total & 34 & 100,0 \\
\hline
\end{tabular}

Berdasar tabel di atas, diketahui bahwa jenis kelamin lansia di Desa Sindanghayu yang menjadi responden penelitian hubungan peranan posbindu dengan peningkatan kesehatan lansia di Desa Sindanghayu Kecamatan Beber Kabupaten Cirebon adalah 23,5\% laki-laki dan 76,5\% perempuan. 
Tabel 2

Distribusi Frekuensi Umur Responden

\begin{tabular}{|c|c|c|}
\hline Umur Responden & $\mathbf{F}$ & $\mathbf{\%}$ \\
\hline 60-65 Tahun & 35 & 44,1 \\
\hline 66-70 Tahun & 19 & 53,9 \\
\hline Total & 34 & 100,0 \\
\hline
\end{tabular}

Berdasar tabel di atas, diketahui bahwa umur lansia di Desa Sindanghayu yang menjadi responden penelitian hubungan peranan posbindu dengan peningkatan kesehatan lansia di Desa Sindanghayu Kecamatan Beber Kabupaten Cirebon adalah $44,1 \%$ berumur $60-65$ tahun dan $53,9 \%$ berumur $66-70$ tahun.

\section{Hasil Analisis Univariat}

Gambaran peranan posbindu di Desa Sindanghayu Kecamatan Beber Kabupaten Cirebon adalah sebagai berikut :

\section{Tabel 3}

Distribusi Frekuensi Peranan Posbindu di Desa Sindanghayu Kecamatan Beber Kabupaten Cirebon

\begin{tabular}{|c|c|c|}
\hline $\begin{array}{c}\text { Peranan } \\
\text { Posbindu }\end{array}$ & F & \% \\
\hline Positif & 16 & 47,1 \\
\hline Negatif & 18 & 52,9 \\
\hline Total & 34 & 100,0 \\
\hline
\end{tabular}

Berdasar tabel di atas, diketahui bahwa peranan posbindu di Desa Sindanghayu yang menjadi responden penelitian hubungan peranan posbindu dengan peningkatan kesehatan lansia di Desa Sindanghayu Kecamatan Beber Kabupaten Cirebon adalah $47,1 \%$ positif dan $52,9 \%$ negatif.

Gambaran peningkatan kesehatan lansia di Desa Sindanghayu Kecamatan Beber Kabupaten Cirebon adalah sebagai berikut :

Tabel 4

Distribusi Frekuensi Peningkatan Kesehatan Lansia di Desa Sindanghayu

\begin{tabular}{|c|c|c|}
\hline Kecamatan Beber Kabupaten Cirebon \\
$\begin{array}{c}\text { Peningkatan } \\
\text { Kesehatan Lansia }\end{array}$ & F & $\%$ \\
\hline Ada Gangguan & 15 & 44,1 \\
\hline Tidak Gangguan & 19 & 55,9 \\
\hline Total & 34 & 100,0 \\
\hline
\end{tabular}

Berdasar tabel di atas, diketahui bahwa peningkatan kesehatan lansia di Desa Sindanghayu yang menjadi responden penelitian hubungan peranan posbindu 
dengan peningkatan kesehatan lansia di Desa Sindanghayu Kecamatan Beber Kabupaten Cirebon adalah $44,1 \%$ ada gangguan dan 55,9\% tidak ada gangguan.

\section{Hasil Analisis Bivariat}

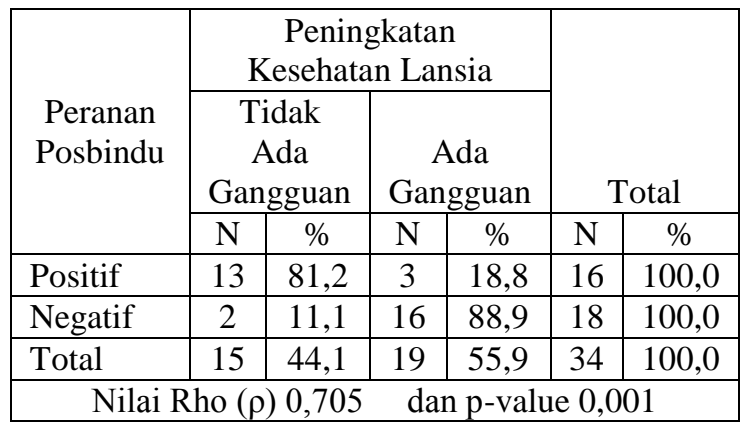

Hasil analisis bivariat hubungan peranan posbindu dengan peningkatan kesehatan lansia di Desa Sindanghayu Kecamatan Beber Kabupaten Cirebon dengan menggunakan uji Korelasi Spearman adalah diketahui bahwa lansia yang menilai peranan posbindu positif, sebagian besar $(81,2 \%)$ peningkatan kesehatannya tidak ada gangguan, sedangkan lansia yang menilai peranan posbindu negatif hanya $11,1 \%$ yang peningkatan kesehatannya tidak ada gangguan. Dari data tersebut terlihat bahwa semakin positif peranan posbindu maka semakin tidak ada gangguan peningkatan kesehatan lansia dan sebaliknya. Dari nilai koefesien korelasi Spearman yaitu Rho $(\rho)=0,705$ dan p-value $0,001<$ a 0,05 maka dapat disimpulkan bahwa Ho berhasil ditolak dan Ha diterima. Artinya terbukti bahwa ada hubungan signifikan peranan posbindu dengan peningkatan kesehatan lansia di Desa Sindanghayu Kecamatan Beber Kabupaten Cirebon.

\section{Pembahasan}

1. Peranan Posbindu di Desa Sindanghayu Kecamatan Beber Kabupaten Cirebon Hasil penelitian menunjukkan bahwa peranan posbindu di Desa Sindanghayu Kecamatan Beber Kabupaten Cirebon adalah 47,1\% positif dan $52,9 \%$ negatif.

Menurut teori Maryunani (2014) peranan posyandu adalah status, kedudukan, hak dan kewajiban yang melakat pada posbindu sebagai wadah, tempat pelayanan terpadu yang diperuntuhkan bagi lansia di suatu daerah tertentu yang di dalamnya terdapat pelayanan kesehatan dan kegiatan peningkatan kesehatan serta kesejahteraan lansia yang dalam pelaksanaanya melibatkan peran masyarakat dan organisasi sosial. Jadi peranan posbindu adalah sebagai pusat kegiatan masyarakat dalam upaya pelayanan kesehatan, perwujudan dari peran serta masyarakat dalam menjaga meningkatkan derajat kesehatan para lansia yang menjadi sasarannya yaitu sasaran langsung kelompok pra usia lanjut (45-59 tahun) kelompok usia lanjut (60 tahun ke atas) kelompok usia lanjut dengan resiko tinggi (70 tahun ke atas) maupun 
sasaran tidak langsung, yang meliputi keluarga dimana usia lanjut berada, masyarakat di lingkungan usia lanjut, organisasi sosial yang peduli terhadap pembinaan kesehatan usia lanjut, petugas lain yang menangani Kelompok Usia Lanjut dan masyarakat luas.

Hasil penelitian ini sesuai dengan hasil penelitian Suhartini, dkk (2012) tentang pengaruh peranan posbindu terhadap kesehatan fisik lansia di Desa Jenggawah Kabupaten Jember tahun 2012 yang salah satu kesimpulannya menyebutkan bahwa peranan posbindu sebagian besar $(52,5 \%)$ dinilai negatif.

Menurut peneliti berdasarkan fenomena di lapangan, peranan posbindu lebih dari separuhnya $(52,9 \%)$ negatif menunjukkan bahwa para sasaran posbindu yaitu lansia menilai bahwa posbindu belum optimal menjalan hak dan kewajibannya sebagai wadah peningkatan kesejahteraan dan kesehatan lasia. Banyak lansia yang menilai posbindu belum maksimal melakukan perannya dalam meningkatkan pengetahuan lansia sehingga mereka memiliki sikap, minat dan motivasi untuk selalu mengikuti kegiatan posbindu sehingga lebih percaya diri dihari tuanya, mendukung peningkatan peningkatan kualitas hidup dan kemandirian usia lanjut yang mengutamakan aspek proaktif dan preventif disamping aspek kuratif dan rehabilitative, memberikan semangat hidup bagi usia lanjut, memberikan keringanan biaya pelayanan kesehatan bagi keluarga yang tidak mampu, memberikan bimbingan pada usia lanjut dalam memelihara dan meningkatkan kesehatanya, agar tetap sehat dan mandiri, meningkatkan jangkauan pelayanan kesehatan lansia di masyarakat, sehingga terbentuk pelayanan kesehatan yang sesuai dengan kebutuhan lansia, mendekatkan pelayanan dan meningkatkan peran masyarakat dalam pelayanan posbindu untuk meningkatkan komunikasi, mengurangi angka kematian lansia di masyarakat, meningkatkan kemampuan petugas puskesmas dalam pembinaan kesehatan usia lanjut yang meliputi perencanaan, pengorganisasian, pelaksanaan, pengendalian, pemantauan dan penilaian termasuk pembinaan dan pengembangan, meningkatkan kemampuan kader dalam memberikan pelayanan kepada usia lanjut, meningkatkan kemampuan petugas puskesmas untuk menggalang peran serta masyarakat dalam pembinaan kesehatan usia lanjut, meningkatkan peran serta usia lanjut, keluarga, kader, organisasi sosial dan lembaga swadaya masyarakat dalam penyelenggaraan pembinaan kesehatan usia lanjut.

Saran dari peneliti bahwa oleh karena masih banyaknya peranan posbindu yang negatif maka diperlukan upaya-upaya agar peranan posbindu meningkat menjadi positif antara lain menyadarkan lansia sasaran posbindu agar menilai peranan posbindu secara objektif, artinya dengan segala keterbatasan pada kader posbindu maka lansia diharapkan dapat memahami untuk tidak terlalu berharap lebih terhadap posbindu. Selain itu dari sisi kader posbindu juga harus terus meningkatkan peranannya dengan cara melakukan perencanan matang atas setiap kegiatan yang akan dilakukan misalnya dengan cara menyesuaikan perencanaan pembinaan kesehatan usia lanjut dalam perencanaan puskesmas, menyesuaikan pengorganisasian dan pelaksanaan pembinaan kesehatan usia lanjut dengan kegiatan pokok lainnya, melakukan kegiatan pembinaan dan pengembangan upaya kesehatan usia lanjut sesuai kondisi dan kebutuhan setempat, mendorong terwujudnya peran serta 
masyarakat khususnya dalam pembinaan kesehatan usia lanjut melalui swadaya masyarakat, PKK dan organisasi lainnya.

2. Peningkatan Kesehatan Lansia di Desa Sindanghayu Kecamatan Beber Kabupaten Cirebon

Hasil penelitian menunjukkan bahwa peningkatan kesehatan lansia di Desa Sindanghayu Kecamatan Beber Kabupaten Cirebon adalah 44,1\% ada gangguan dan $55,9 \%$ tidak ada gangguan.

Menurut teori Kasdu (2012) kesehatan lansia adalah kondisi atau keadaan fisik lansia dalam melakukan aktivitas sehari-hari. Kesehatan fisik lansia akan sangat menentukan kemampuan lansia dalam melakukan aktivitas atau kegiatan sehari-hari. Lansia dikatakan memiliki kesehatan fisik yang baik apabila lansia masih mampu melakukan aktivitas atau kegiatan sehari-hari tanpa bantuan sama sekali atau mandiri, sedangkan kesehatan fisik lansia dianggap ada gangguan jika lansia dalam melakukan aktivitas atau kegiatan sehari-hari kadang-kadang perlu bantuan dan kesehatan fisik lansia dikatakan buruk jika lansia tidak mampu melakukan aktivitas atau kegiatan sehari-hari sehingga sangat tergantung dengan orang lain. Kesehatan fisik ini bukan terjadi karena lansia cacat namun karena kondisi fisiknya yang memang sudah terjadi penurunan akibat perubahan-perubahan fisiologis menua. Perubahan fungsi organ tubuh yang berkaitan dengan kesehatan fisik yang terjadi pada periode lansia antara lain perubahan fisik bukan lagi pertumbuhan tetapi pergantian dan perbaikan sel-sel tubuh, penurunan mitosis menyebabkan kecepatan jumlah sel yang rusak tidak seimbang dengan jumlah sel yang baru. Keadaan ini menyebabkan tubuh lebih banyak kehilangan sel, daripada jumlah sel yang baru sebagai pengganti. Diperkirakan orang berusia antara umur $65-$ 70 tahun akan kehilangan $20 \%$ dari keseluruhan sel-sel saraf yang dimilikinya, pertumbuhan dan reproduksi sel-sel menurun. Pada proses ini terjadi banyak kegagalan dalam pergantian sel-sel tersebut sehingga lansia lebih lama sembuh apabila mengalami sakit. Kehilangan sel-sel tubuh, kondisi ini menyebabkan penurunan kekuatan dan efisiensi fungsi tubuh, dan kemampuan indera perasa pada lansia. Hal ini terkait dengan perubahan otot, yaitu terjadinya penurunan zat kolagen yang berfungsi untuk menjaga elastisitas. Pada umumnya perubahan pada masa lansia meliputi perubahan dari tingkat sel sampai ke semua sistem organ tubuh, diantaranya sistem pernafasan, pendengaran, penglihatan, kardiovaskuler, sistem pengaturan tubuh, muskuloskeletal, gastrointestinal, genito urinaria, endokrin dan integument. Ciri - ciri perubahan fisik masa usia lanjut akan berpengaruh juga pada kondisi kesehatannya, seperti keadaan tubuh: Kadar lemak dalam tubuh meningkat akibat penurunan aktivitas fisik dan kurang makanan berserat. Daya motorik otot menurun membuat orang sulit bergerak. Jumlah air di dalam tubuh berkurang. Massa tulangpun menurun karena kondisi tulang mulai rapuh, sementara pertumbuhan tulang sudah berhenti. Pencernaan: Gangguan pada gigi dan perubahan bentuk rahang mengakibatkan sulitnya mengunyah makanan. Daya penciuman dan perasa menurun, hal ini menyebabkan turunnya selera makan yang berakibat kekurangan gizi. Menurunnya produksi asam lambung dan enzim pencernaan, mempengaruhi 
penyerapan vitamin dan zat-zat lain pada usus. Penurunan perkembangan lapisan otot pada usus, melemahkan dinding usus, dan menurunkan daya cerna usus. Fungsi hati yang memproses racun, seperti obat-obatan dan alkohol pun melemah. Kekebalan tubuh: Akibat berkurangnya kemampuan tubuh memproduksi antibodi pada masa lansia, sistim kekebalan tubuhpun menurun. Hal ini membuat lansia rentan terhadap berbagai macam penyakit. Jantung: Daya pompa jantung menurun karena elastisitas pembuluh arteri melemah, semua ini akibat perubahan kolagen dan elastin dalam dinding arteri. Pernafasan: Fungsi paru-paru menurun akibat berkurangnya elastisitas serabut otot yang mempertahankan pipa kecil dalam paru-paru tetap terbuka.

Hasil penelitian ini sesuai dengan hasil penelitian Suhartini, dkk (2012) tentang pengaruh peranan posbindu terhadap kesehatan fisik lansia di Desa Jenggawah Kabupaten Jember tahun 2012 yang salah satu kesimpulannya menyebutkan bahwa kesehatan fisik lansia sebagian besar $(60,0 \%)$ mengalami gangguan.

Menurut peneliti, berdasarkan hasil pengamatan fenomena di lapangan masih banyaknya lansia yang peningkatan kesehatannya mengalami gangguan disebabkan berbagai faktor, salaj satunya adalah akibat merokok dan kurang olah raga. Kedua aktivitas tersebut akan mempengaruhi otak dan saraf. Menurunnya kemampuan fungsi otak melemahkan daya ingat. Akibatnya, orang lansia suka sering lupa makan atau minum obat, yang pada akhirnya akan menimbulkan penyakit. Metabolisme tubuh: Penurunan fungsi hormon dalam tubuh. Penurunan hormon seks pada wanita terjadi menjelang menopause. Ekskresi: Penurunan aliran darah ke ginjal karena berkurangnya jumlah nefron, yaitu unit yang berfungsi mengekstrak kotoran dari darah dan membuangnya ke urine. Hal ini menyebabkan peningkatan volume urine dan frekuensi pengeluaran urine. Tulang: Pengurangan massa tulang karena pertambahan usia. Hal ini juga disebabkan kurangnya mengkonsumsi makanan yang mengandung zat $\mathrm{Ca}$ (kalsium), jarang berolahraga, menopause dini, dan hilangnya selera makan (anoreksia).

3. Hubungan Peranan Posbindu Dengan Peningkatan Kesehatan Lansia Di Desa Sindanghayu Kecamatan Beber Kabupaten Cirebon

Hasil penelitian dan analisis bivariat korelasi Spearman diketahui bahwa lansia yang menilai peranan posbindu positif, sebagian besar $(81,2 \%)$ peningkatan kesehatannya tidak ada gangguan, sedangkan lansia yang menilai peranan posbindu negatif hanya $11,1 \%$ yang peningkatan kesehatannya tidak ada gangguan. Dari data tersebut terlihat bahwa semakin positif peranan posbindu maka semakin tidak ada gangguan peningkatan kesehatan lansia dan sebaliknya.

Dari nilai koefesien korelasi Spearman yaitu Rho $(\rho)=0,705$ dan p-value $0,001<\alpha 0,05$ maka dapat disimpulkan bahwa Ho berhasil ditolak dan Ha diterima. Artinya terbukti bahwa ada hubungan signifikan peranan posbindu dengan peningkatan kesehatan lansia di Desa Sindanghayu Kecamatan Beber Kabupaten Cirebon tahun 2018.

Hasil penelitian ini sesuai dengan teori dari Komnas Lansia (2013) yang menjelaskan bahwa posbindu adalah suatu forum komunikasi alih tehnologi 
dan pelayanan bimbingan kesehatan masyarakat oleh dan untuk masyarakat yang mempunyai nilai strategis dalam mengembangkan sumber daya manusia sejak dini. Posbindu adalah sebuah wadah, tempat pelayanan terpadu yang diperuntuhkan bagi lansia di suatu daerah tertentu yang di dalamnya terdapat pelayanan kesehatan dan kegiatan peningkatan kesehatan serta kesejahteraan lansia yang dalam pelaksanaanya melibatkan peran masyarakat dan organisasi sosial. Jadi bisa ditarik kesimpulan dari pengertian diatas bahwa posbindu adalah suatu bentuk pelayanan kesehatan oleh masyarakat, dari masyarakat, untuk masyarakat dan untuk mensejahterakan lansia yang menjadi sasaran posbindu. Sasaran posbindu yaitu para lansia yaitu sasaran sasaran langsung kelompok pra usia lanjut (45-59 tahun) kelompok usia lanjut (60 tahun ke atas) kelompok usia lanjut dengan resiko tinggi (70 tahun ke atas). Dan sasaran tidak langsung, yang meliputi keluarga dimana usia lanjut berada, masyarakat di lingkungan usia lanjut, organisasi sosial yang peduli terhadap pembinaan kesehatan usia lanjut, petugas lain yang menangani Kelompok Usia Lanjut dan masyarakat luas.

Sesuai dengan sasarannya maka posbindu memiliki peranan sebagai tempat pelayanan peningkatan kesehatan lansia. Peranan tersebut diwujudkan dalam upaya meningkatkan pengetahuan lansia sehingga mereka memiliki sikap, minat dan motivasi untuk selalu mengikuti kegiatan posbindu sehingga lebih percaya diri dihari tuanya, mendukung peningkatan peningkatan kualitas hidup dan kemandirian usia lanjut yang mengutamakan aspek proaktif dan preventif disamping aspek kuratif dan rehabilitative, memberikan semangat hidup bagi usia lanjut, memberikan keringanan biaya pelayanan kesehatan bagi keluarga yang tidak mampu, memberikan bimbingan pada usia lanjut dalam memelihara dan meningkatkan kesehatanya, agar tetap sehat dan mandiri, meningkatkan jangkauan pelayanan kesehatan lansia di masyarakat, sehingga terbentuk pelayanan kesehatan yang sesuai dengan kebutuhan lansia, mendekatkan pelayanan dan meningkatkan peran masyarakat dalam pelayanan posbindu untuk meningkatkan komunikasi, mengurangi angka kematian lansia di masyarakat, meningkatkan kemampuan petugas puskesmas dalam pembinaan kesehatan usia lanjut yang meliputi perencanaan, pengorganisasian, pelaksanaan, pengendalian, pemantauan dan penilaian termasuk pembinaan dan pengembangan, meningkatkan kemampuan kader dalam memberikan pelayanan kepada usia lanjut, meningkatkan kemampuan petugas puskesmas untuk menggalang peran serta masyarakat dalam pembinaan kesehatan usia lanjut, meningkatkan peran serta usia lanjut, keluarga, kader, organisasi sosial dan lembaga swadaya masyarakat dalam penyelenggaraan pembinaan kesehatan usia lanjut.

Juga sesuai dengan teori Depkes RI (2012) bahwa posbindu dapat menjalankan perannya sebagai wadah aktivitas kesehatan lansia karena posbindu memiliki perencanaan untuk mengoptimalisasikan peranan posbindu tersebut maka mutlak diperlukan suatu perencanaan yaitu menyesuaikan perencanaan pembinaan kesehatan usia lanjut dalam perencanaan puskesmas, menyesuaikan pengorganisasian dan pelaksanaan pembinaan kesehatan usia lanjut dengan kegiatan pokok lainnya, melakukan kegiatan pembinaan dan pengembangan upaya kesehatan usia lanjut sesuai kondisi dan kebutuhan 
setempat, mendorong terwujudnya peran serta masyarakat khususnya dalam pembinaan kesehatan usia lanjut melalui swadaya masyarakat, PKK, organisasi lainnya. Posbindu juga dapat berperan efektif dalam peningkatan kesehatan lansia karena pelaksanaan kegiatannya mencakup secara umum kegiatan pelaksanaan promotif dan preventif. Kegiatan promotif, dilakukan bertujuan untuk meningkatkan gairah hidup para usia lanjut agar merasa tetap dihargai dan tetap berguna . upaya promotif juga ditunjukan kepada keluarga dan masyarakat di lingkungan usia lanjut. Kegiatan ini berperan upaya penyuluhan mengenai perilaku hidup sehat, pengetahuan tentang gizi usia lanjut, pengetahuan tentang proses denegeratif yang akan terjadi pada usia lanjut, upaya meningkatkan kesegaran jasmani serta upaya lain yang dapat memelihara kemandirian serta produktifitas usia lanjut. Sedangkan kegiatan preventif, dilakukan bertujuan untuk mencegah sedini mungkin terjadinya penyakit dan komplikasi yang di akibatkan oleh proses degeneratif. Kegiatan yang di lakukan berupa deteksi dini kesehatan usia lanjut yang dapat dilakukan di kelompok atau di Puskesmas.

Peranan posbindu terhadap peningkatan kesehatan fisik lansia dapat terwujud karena dalam posbindu dilakukan berbagai kegiatan yang sifatnya menunjang peningkatan kesehatan lansia baik kesehatan fisik maupun kesehatan mental. Jadi jika lansia rajin mengikuti berbagai kegiatan di posbindu maka ia akan mendapatan berbagai manfaat yang secara langsung maupun tidak langsung dapat meningkatkan kesehatan fisik lansia.

Hasil penelitian juga sesuai dengan teori Ahmad (2014) bahwa jika peranan posbindu bisa terwujud dengan baik (positif) maka peningkatan kesehatan lansia juga akan semakin baik (tidak ada gangguan kesehatan) dan sebaliknya jika peranan posbindu tidak terwujud dengan baik (negatif) maka peningkatan kesehatan lansia juga tidak baik (ada gangguan kesehatan.

Hasil penelitian ini sesuai dengan hasil penelitian Arimbi, dkk (2010) tentang faktor-faktor yang berhubungan dengan kesehatan lansia di Desa Kertabumi Kabupatan Sukabumi yang salah satu kesimpulannya menyebutkan bahwa ada hubungan signifikan peranan posbindu dengan kesehatan lansia dengan p-value 0,002 .

Juga sesuai dengan hasil penelitian Suhartini, dkk (2012) tentang pengaruh peranan posbindu terhadap kesehatan fisik lansia di Desa Jenggawah Kabupaten Jember tahun 2012 yang salah satu kesimpulannya menyebutkan bahwa terbukti ada pengaruh signifikan peranan posbindu terhadap kesehatan fisik lansia dengan p-value 0,007. 


\section{KESIMPULAN DAN SARAN}

\section{Kesimpulan}

1. Peranan posbindu di Desa Sindanghayu Kecamatan Beber Kabupaten Cirebon adalah $47,1 \%$ positif dan $52,9 \%$ negatif.

2. Peningkatan kesehatan lansia di Desa Sindanghayu Kecamatan Beber Kabupaten Cirebon adalah 45,1\% tidak ada gangguan dan 55,9\% ada gangguan.

3. Ada hubungan signifikan peranan posbindu dengan peningkatan kesehatan lansia di Desa Sindanghayu Kecamatan Beber Kabupaten Cirebon dengan pvalue 0,001 dan Rho $(\rho) 0,795$.

\section{Saran}

1. Untuk Lansia

Para lansia hendaknya lebih aktif lagi memanfaatkan pelayanan kesehatan di Posbindu dan selalu aktif mendukung setiap kegiatan posbindu agar peranan posbindu sebagai wadah untuk meningkatkan kesejateraan dan optimal.

2. Untuk Keluarga Lansia

Anggota keluarga lansia hendaknya lebih memperdalam pengetahuannya tentang koping lansia sehingga dapat berperan optimal dalam memberikan dukungan kesehatan bagi anggota keluarganya yang sudah lansia.

3. Untuk Kader Posbindu

Kader Posbindu hendaknya lebih intensif lagi melakukan pendekatan interpersonal kepada lansia dan keluarganya agar para lansia aktif mengunjungi posyandu lansia untuk pemeriksaan fisik dan kesehatan lansia secara rutin.

4. Untuk Tenaga Kesehatan / Bidan

Bidan hendaknya memberikan perhatian lebih kepada kegiatan posbindu dibanding posyandu, karena posbindu masih belum berjalan secara optimal

5. Peneliti Lain

Perlu dilakukan penelitian lanjutan tentang peningkatan kesehatan lanis lansia ditinjau dari faktor lain selain faktor peranan posbindu.

\section{DAFTAR PUSTAKA}

Arikunto, Suharsimi,2010, Manajemen Penelitian, Jakarta : Rineka Cipta

Ahmad, 2014, Sosial Budaya Kebidanan, Cirebon : SCS Press

Depkes RI, 2017, Profil Kesehatan Indonesia tahun 2016. Jakarta , 2011, Penatalakksanaan Lansia, Jakarta ,2010, Pedoman Kader Posbindu, Jakarta 2012, Standar Pelayanan Posyandu Lansia, Jakarta

Komnas Lansia, 2017, Laporan dan Evaluasi Program Lansia tahun 2016, Jakarta ,2013, Pedoman Pengelolaan Posyandu Lansia, Jakarta

Kasdu, Abdullah, 2010. Manajemen Pelayanan Kesehatan Masyarakat, Jakarta : EGC

Maryunani, 2014, Kebidanan Komunitas, Jakarta : TIM 
Notoatmodjo, Soekidjo, 2003, Promosi Kesehatan, Jakarta : Rineka Cipta , 2012, Metodologi Penelitian Kesehatan, Jakarta : Rineka Cipta

Sugiyono, 2009, Metodologi Penelitian Kualitatif, Kuantitatif dan $R \& D$, Bandung : Alfabeta

Sulistyaningsih, 2011, Metodologi Penelitian Kebidanan, Yogya : Numed

Suhartini, dkk. 2012. Pengaruh peranan posbindu terhadap kesehatan fisik lansia di Desa Jenggawah Kabupaten Jember tahun 2012. Skripsi. 